Tuscan for a three-year voyage. His account of this was published in 1840.4 Bennett collected a large number of botanical and zoological specimens, which he presented to the Hunterian Museum of the Royal College of Surgeons of England, the Linnaean Society, and King's College London.

As the Tuscan travelled north, across the Equator to colder waters on the west coast of America, many of the crew developed a profuse eruption on the skin of minute vesicles, attended with intense itching upon exposure to the cold. It is not clear what this was, but one possibility is sensitization to the marine animal, resembling seaweed, called Alcyonidium gelatinosum, and as such Beale's description bears a relation to that ailment of North Sea fishermen known as "Dogger Bank Itch".

Of considerable interest is Bennett's account of an illness following the ingestion of salted albacore or tunny. A few hours after the meal, the affected men became febrile, complained of headaches, and broke out in a "scarlet rash". The illness was not brought on by eating fresh tunny and was short-lived. I believe that this is an early, if not the earliest, account of scombrotoxic poisoning, which results from eating tuna, bonito, or mackerel, the flesh of which has become toxic as a result of bacterial contamination and growth. It is a form of histamine poisoning in which there is a brief, non-fatal illness of headache, fever, diarrhoea, and a bright red rash. The incubation period is a matter of hours, the onset abrupt, and the illness lasts from three to six hours and is always over by twenty-four hours. Although as little as $20 \mathrm{mg}$ histamine $/ 100 \mathrm{~g}$ flesh may cause symptoms, the usual dose is in excess of $100 \mathrm{mg} / 100 \mathrm{~g} .^{\mathrm{s}}$

The great days of whaling are over. In the early part of this century factory ships were developed and accelerated the decline of an industry that had already squandered the resources on which it depended. These factory ships brought a new dimension of health care to the whaling crews; and a new literature of life in the frozen south emerged in which medical writers have made their own contributions. Three examples of modern medical writers may be cited. ${ }^{6,7,8}$ Excellent though these be, they cannot equal in importance the early writings of the whaling surgeons.

The second paper was presented by Dr David Wright with the title:

\title{
ARSENIC AT ST ANDREWS, 1943
}

On 15 and 16 January 1943, there was an outbreak of acute arsenical poisoning in St Andrews, following the consumption of contaminated sausages. As a result, one

4 F. D. Bennett, Narrative of a whaling voyage round the globe from the year 1833 to 1836 , London, Richard Bentley, 1840, 2 vols.

${ }^{3}$ R. J. Gilbert, G. Hobbs, C. K. Murray, J. G. Cruickshank, and Susan E. J. Young, 'Scombrotoxic fish poisoning; features of the 50 incidents to be reported in Britain (1976-9)' Br. med. J., 1980, 281: 71-72.

6 A. Conan Doyle, Memories and adventures, London, Hodder \& Stoughton, 1924.

${ }^{7}$ H. R. Lillie, 'With whales and seals', Br. med. J., 1949, ii: 1467-1468.

R. B. Robertson, Of whales and men, London, Macmillan, 1956. 


\section{Report of Proceedings 1981-82}

hundred and fifty people at least were ill; two of them - and a dog - died. ${ }^{1}$

The sausages were made locally in three forty-pound batches on the morning of 15 January. It would appear from subsequent investigation that about half a pound of white arsenic (arsenic trioxide) was added to the first batch, producing sausages or sausage-meat containing about $5 \mathrm{~g}$ of arsenic per one pound. Some subsequent contamination of the second and third batches produced sausages with contents of about $500 \mathrm{mg}$ of arsenic per one pound and $250 \mathrm{mg}$ per one pound respectively.

None of the assistants who made the sausages that morning admitted any departure from normal procedure, and the possibility that other people had interfered was discounted. The sausages were sold to the general public and to a male residence of $\mathrm{St}$ Andrews University, St Salvator's Hall.

Symptons of acute arsenical poisoning rapidly followed at St Salvator's Hall, where sausages from the second and third batches were eaten for lunch as "toad in the hole". About ninety students were affected, some quite seriously, although none died. The two deaths occurred in townsfolk. The first, a man, died about twenty-four hours after eating four sausages from the first batch, containing about $2.5 \mathrm{~g}$ of arsenic. The second, a woman, ate three sausages from the same batch and died twelve hours later.

Pathological examination following these deaths and the other illnesses, confirmed arsenic both in the sausages and in specimens from the victims. The public were alerted and no further deaths occurred. This in itself was remarkable; as $200 \mathrm{mg}$ of arsenic may prove fatal, the contaminated food might have killed hundreds.

Further investigations by the public health authorities and the police failed to show how the arsenic had been put into the sausage mix, or even where the arsenic could have come from. No chemist's shop normally carried such a weight, and no laboratory or store had reported a theft. Moreover, restrictions under the Arsenic Act 1851, meant that all sales of arsenic had to be recorded and they could only be made where the vendor knew the buyer personally or knew someone who was prepared to guarantee the buyer. Large quantities of the poison could, however, be obtained from wholesalers with much less restriction. Arsenic trioxide was used as a rodenticide, as a sheep dip, and as a herbicide, and as the first of these it might have been found in shops, possibly not very clearly distinguished from other white compounds.

While it is interesting to speculate on deliberately dark motives, for instance, wartime St Andrews University had a number of serving RAF officers as short-term students, it is perhaps more likely that the poisoning was accidental. A follow-up study of the survivors, performed in 1978, did not disclose any serious chronic problems that could clearly be attributed to the acute exposure to arsenic in $1943 .{ }^{2}$

This meeting, held in such attractive and historic surroundings, brought the session to a fitting end.

William Cunningham, President
H. P.

${ }^{1}$ G. Matthew Fyfe and B. W. Anderson, 'Outbreak of acute arsenical poisoning', Lancet, 1943, ii: 614-615.

${ }^{2}$ J. H. Renwick and J. M. A. Lenihan, 'Long term effects of acute arsenical poisoning', J. Soc. Occup. Med., 1981, 31: 144-146. 